\title{
The Impact of Celebrity Endorsement on Brand Loyalty: Mediating and Moderating Mechanisms
}

\author{
Regina Burnasheva ${ }^{1}$, Yong Gu Suh ${ }^{2}$ \\ ${ }^{1} \mathrm{PhD}$ Candidate, Sookmyung Women's University, Cheongpa-ro 47-gil 100, Seoul, Korea \\ 2 Professor of Marketing, Sookmyung Women's University, Cheongpa-ro 47-gil 100, Seoul, Korea \\ Correspondence: Regina Burnasheva, PhD Candidate, Sookmyung Women's University, Cheongpa-ro 47-gil \\ 100, Seoul, Korea.
}

Received: December 16, 2020

Accepted: January 4, 2021

Online Published: January 8, 2021

doi:10.5539/ibr.v14n2p29

URL: https://doi.org/10.5539/ibr.v14n2p29

\begin{abstract}
Applying the meaning transfer theory, the purpose of this study is to proffer a theoretical framework in which celebrity endorser's credibility (CEC) effects the brand loyalty through the mediating role of brand relationship quality and the moderating role of the celebrity-brand congruence. Data was gathered through an online survey from young Korean millennials and tested using structural equation modeling and multi-group techniques. The findings revealed that brand relationship quality serves as a partial mediator of the effect of CEC on brand loyalty. The findings also suggested that celebrity-brand congruence acts as a moderator between CEC and the brand relationship quality. This study offers useful practical implications for luxury marketers and advertisers.
\end{abstract}

Keywords: celebrity endorsement, brand relationship quality, celebrity-brand congruence, brand loyalty, Korean millennials.

\section{Introduction}

Celebrity endorsements play a significant role in marketing and advertising as a popular tool for promoting brands. Celebrity endorsers are personalities enjoying the public recognition and they take advantage of this recognition in representing consumer good through advertisement (McCracken, 1989, p. 310). They possess aspirational, symbolic associations (Escalas, 2004) and differential characteristics such as attractiveness, expertise and trustworthiness (Ohanian, 1990), which play an essential role in forming credibility. Celebrity endorser's credibility (CEC) has received substantial attention in prior research and was linked to a series of outcomes such as brand equity (Spry et al., 2011; Dwivedi et al., 2015), brand evaluation (Dwivedi et al., 2014; Stafford et al., 2002), brand attitude (Wang et al., 2017), and relationship quality (Dwivedi et al., 2016). Although past studies have offered essential contributions, relatively little is known about the mediating (brand relationship quality) and moderating (celebrity-brand congruence) mechanisms in this relation between CEC and brand loyalty.

To address these issues, by applying the meaning transfer theory, the purpose of this study is to proffer a theoretical framework in which CEC effects the brand loyalty through the mediating role of brand relationship quality and the moderating role of the celebrity-brand congruence. More specifically, this study explores the followings: (i) brand relationship quality mediating effect to the association between CEC and brand loyalty; and (ii) the moderating role of celebrity-brand congruence in the association between CEC and brand relationship quality construct.

The rest of this study is structured as follows wherein the next part, literature related to key constructs, including brand relationship quality and celebrity-brand congruence are described and hypotheses are formulated. Next, the data collection methods and data analysis are discussed. Research concludes with contributions, shortcomings, and future research directions.

\section{Literature Review and Hypotheses Development}

\subsection{The Mediating Role of Brand Relationship Quality}

Veloutsou (2007) and Fournier (1998) stated that a brand relationship or consumer-brand relationship is the interaction that customers feel, think and have with a brand. It builds on a metaphor that states customers form 
relationships with brands in a similar way to human relations (McAlexander et al., 2002; Fournier, 1998). Specifically, according to the study of Aaker (1996), when customers develop a relationship with brands, they can build an active connection with those brands similar with those individuals when having a bond with their friends.

Many researchers consider consumer-brand relationships through two theoretical perspectives, namely brand love approach (Albert and Merunka, 2013; Caroll and Ahuvia, 2006) and brand commitment approach (Chaudhuri and Holbrook, 2001; Giovanis and Athanasopoulou, 2017). Fournier (1998) and Valta (2013) view consumer brand relationships through the approach of brand relationship quality. Fournier (1994) described this as "customer-based indicator of the strength and depth of a person-brand relationship" (p. 124) and conceptualized this as a multifaceted paradigm consisting of seven dimensions. This paper applied the brand relationship quality approach where it considered as a multidimensional construct comprising three dimensions.

Given the significance of consumer-brand relationships in celebrity endorsements process (Dwivedi et al., 2015; Dwivedi and Johnson, 2013), it is necessary to investigate the impact of CEC on brand relationship quality. Previous studies have conceptualized the construct of brand relationship quality as trust, commitment, social benefits (Dwivedi et al., 2015); brand trust, brand attachment and brand commitment (Ramaseshan and Stein, 2014); the relationship commitment, relationship satisfaction and trust (Valta, 2013); the brand trust and brand satisfaction (Crosby et al., 1990; Hess and Story, 2005); brand attachment, brand satisfaction and brand trust (Esch et al., 2006). In the present study, brand relationship quality refers as distinguished by individuals as their trust to and satisfaction with a brand, along with attachment. Trust is a factor defined as the customer perception of credibility and benevolence (Doney and Cannon, 1997). Brand attachment refers to the emotional tie connecting the customer with a brand (Park et al., 2010), while brand satisfaction refers to "consumer's pleasurable fulfilment" response (Oliver, 1999, p. 34). In this study, the relationship-based construct (brand trust, brand attachment and brand satisfaction) might advance understanding for brand relationship quality of celebrity endorsement literature.

Through the usage of meaning transfer theory, the influence of CEC on brand relationship quality is explained (McCracken, 1989). This theory states that the perceptions of celebrity endorsers as credible are transferred to the endorsed brand (McCracken, 1989), and then from the brand to the customer through creating relational bonds. Dwivedi and Johnson (2013) also emphasizes that celebrity endorsers that are viewed as credible can potentially generate positive relational consequences towards the endorsed brand.

Brand relationship quality is not only directly associated with brand loyalty, but also can act as a mediator (Francisco-Maffezzoli et al., 2014; Roberts et al., 2013; Veloutsou, 2015; Valta, 2013). According to relationship marketing theory, customers perceive the strength of the relationship from the customers' behavior in that relationship (Hunt et al., 2006). Thus, customers who feel attached to the brand tend to hold more favorable feelings, thereby increasing their brand loyalty. Valta (2013) states that consumers who are more positive in the perception of brand relationship quality, are more willing to remain loyal to the product. Based on these insights, the link between CEC and brand loyalty can be strengthened by brand relationship quality.

Therefore, the first hypothesis states the following:

H1. Brand relationship quality would mediate the link between CEC and brand loyalty.

\subsection{The Moderating Role of Celebrity-Brand Congruence}

Congruence is one of the most essential central constructs in the research area of endorsement. The term congruence has been added multiple synonyms and is often used interchangeably with a wide variety of other terms such as fit, match up effect, and link.

Misra and Beatty (1990) had defined celebrity-brand congruence and they refer to this as the extent to which a celebrity's distinctive features coincides with the explicit attributes of the brand. According to Spry et al., (2011), celebrity-brand congruence refers to the degree to which people embrace a celebrity-brand fit as appropriate and logical. The more appropriate and relevant this fit, the more individual accepts the meaning. As the transfer meaning theory suggests, celebrity's meaning and associations transmit to the brand via the endorsement and then from the brand to the user via behaviors. Such a process, based on celebrity-brand congruence, facilitates the formation an associative link, thereby increasing the transfer from one to the other. Previous studies have emphasized the importance of celebrity-brand congruence in fostering brand outcomes such as brand commitment (Albert et al., 2017; Dwivedi et al., 2015), brand attitudes (Gong and Li, 2017; Misra and Beatty, 1990; Min et al., 2019), and brand identification (Albert et al., 2017). In addition, celebrity-brand congruence was revealed to moderate the association between endorser credibility and brand equity (Dwivedi et al., 2015) as 
well as the association between endorser credibility and brand evaluation (Dwivedi et al., 2014). Thus, it is logical to deduce that celebrity-brand congruence may moderate the relationship between CEC and brand relationship quality. Based on the above arguments, the link between CEC and brand relationship quality may be moderated by celebrity-brand congruence. Thus, the following hypotheses are stated:

H2. Celebrity-brand congruence would moderate the link between CEC and brand relationship quality, such that the link is stronger when celebrity-brand congruence is high.

In figure 1, the integrated model used in this study was illustrated.

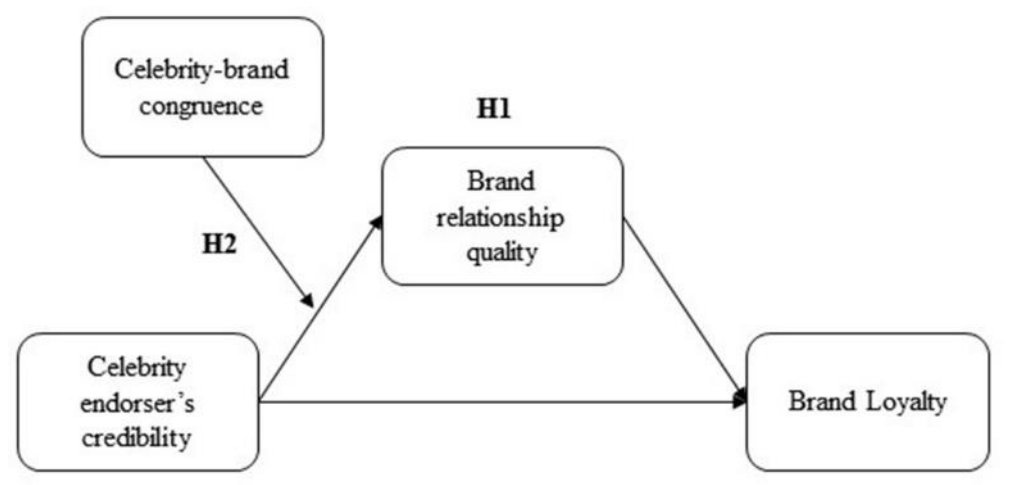

Figure 1. Research model

\section{Research Method}

\subsection{Sample and Data Collection}

Prior to conducting online survey, a pre-test was performed with eighteen respondents. The respondents were requested to recall the names of the Korean celebrities and their associated luxury brands. Two pairings with higher ratings such as KAI (EXO) - Gucci and G Dragon (Big Bang) - Chanel were retained for this study.

An online survey was employed via the research firm in South Korea. A total of 302 Korean respondents participated in the survey, and 297 usable responses were obtained.

The majority of the participants were females (57\%) in their twenties (54\%). In terms of educational background, $64 \%$ held a university degree. Furthermore, $42 \%$ were employees with a monthly household income between 2000USD to 4000USD (42\%).

\subsection{Instrument Design}

The online questionnaire of the paper consisted of 24 items on a 7-point Likert scale. Ohanian (1990) had developed the measures of three items for CEC. For brand relationship quality, six items are derived from Chaudhuri and Holbrook (2001); Park et al., (2010); and Tsiros and Mittal (2000) tapped brand trust, attachment and satisfaction dimensions. Next, three items from Spry et al., (2011); Till and Busler (2000) measured celebrity-brand congruence construct. Finally, brand loyalty was assessed with three items from the scale in Veloutsou (2015).

\section{Findings}

\subsection{Preliminary Analysis}

Before conducting the main analysis, a series of preliminary analyses were undertaken. Confirmatory factor analysis (CFA) through the software of AMOS 22.0 was first applied to assess the validity of the constructs. The CFA revealed a good fit to the data $(\mathrm{CMIN} / \mathrm{df}=2.31, \mathrm{GFI}=0.919, \mathrm{NFI}=0.941, \mathrm{TLI}=0.957, \mathrm{CFI}=0.965$, RMSEA $=0.066$ ), with all factor loadings exceeding the recommended minimum of 0.70 by Nunnally (1978). This suggested threshold is also exceeded in the assessed reliability by the Cronbach's a of each construct. Composite reliability (CR) and the average variance extracted (AVE) evaluated further the convergent validity. The AVEs and CRs of all the constructs were greater than 0.50 and 0.70, respectively (Hair et al., 2012). In Table 1, the factor loadings, Cronbach's a, AVEs and CRs are summarized. 
Table 1. Scale factor loadings

\begin{tabular}{|c|c|c|c|c|c|}
\hline Construct & Items & Factor loadings & Cronbach a & AVE & CR \\
\hline \multirow[t]{3}{*}{ CEC } & CEC1 & 0.78 & 0.81 & 0.68 & 0.87 \\
\hline & CEC2 & 0.78 & & & \\
\hline & CEC3 & 0.75 & & & \\
\hline \multirow[t]{6}{*}{ BRQ } & BT1 & 0.77 & 0.90 & 0.63 & 0.91 \\
\hline & BT2 & 0.82 & & & \\
\hline & BA1 & 0.80 & & & \\
\hline & BA2 & 0.73 & & & \\
\hline & BS1 & 0.76 & & & \\
\hline & BS2 & 0.72 & & & \\
\hline \multirow[t]{3}{*}{$\mathrm{CBC}$} & $\mathrm{CBC} 1$ & 0.89 & 0.94 & 0.87 & 0.95 \\
\hline & $\mathrm{CBC} 2$ & 0.92 & & & \\
\hline & CBC3 & 0.93 & & & \\
\hline \multirow[t]{3}{*}{ BL } & BL1 & 0.83 & 0.87 & 0.74 & 0.90 \\
\hline & BL2 & 0.84 & & & \\
\hline & BL3 & 0.84 & & & \\
\hline
\end{tabular}

Note: $\mathrm{CEC}=$ Celebrity endorser's credibility; $\mathrm{BRQ}=$ Brand relationship quality; $\mathrm{CBC}=$ Celebrity-brand congruence; $\mathrm{BL}=$ Brand loyalty.

Finally, following the suggested criteria of Fornell and Larcker (1981) that if square root of AVEs were larger than the inter-construct associations, the discriminant validity is confirmed and this is shown in Table 2.

Table 2. Correlation matrix and the square root of AVE

\begin{tabular}{llllll}
\hline Construct & CEC & BRQ & CBC & BL & Sq. R \\
\hline CEC & 1 & & & 0.825 \\
BRQ & $0.776^{* *}$ & 1 & & 0.793 \\
CBC & $0.709^{* *}$ & $0.781^{* *}$ & 1 & & 0.933 \\
BL & $0.776^{* *}$ & $0.800^{* *}$ & $0.671^{* *}$ & 1 & 0.860 \\
\hline
\end{tabular}

Note: $\mathrm{CEC}=$ Celebrity endorser's credibility; $\mathrm{BRQ}=$ Brand relationship quality; $\mathrm{CBC}=$ Celebrity-brand congruence; $\mathrm{BL}=$ Brand loyalty.

$* * \mathrm{p}<0.01$ levels

\subsection{The Mediating Effect of Brand Relationship Quality}

"Questions about cause-effect relations invoke the idea of mediation, the process by which some variables exert influences on others through intervening or mediator variables" (Preacher and Hayes, 2008, p. 879). It was anticipated that brand relationship quality would mediate the link between CEC and brand loyalty in Hypothesis 1. To test the first hypothesis, the bootstrapping procedure with 5000 cases at 95 percent-confidence intervals (CIs) in AMOS was implemented. It suggests that there is mediation if the CI does not contain zero (Preacher et al., 2007). As revealed by Table 3, the indirect path from CEC to brand loyalty via brand relationship quality was positive and significant $(\beta=0.39,95 \%$ CI: $0.24-0.56$ ), yielding support for Hypothesis 1 . Nevertheless, brand relationship quality partially mediated the path from CEC to brand loyalty as the direct effect of this link was substantial ( $\beta=0.38,95 \%$ CI: 0.13-0.62).

Table 3. Results of mediation analysis

\begin{tabular}{|c|c|c|c|c|c|}
\hline \multirow[t]{2}{*}{ Hypothesis } & \multirow[t]{2}{*}{$\beta$} & \multirow[t]{2}{*}{ SE } & \multicolumn{2}{|c|}{$95 \%$ CI } & \multirow[t]{2}{*}{ Test results } \\
\hline & & & Lower & Upper & \\
\hline & $0.39 * * *$ & 0.08 & 0.24 & 0.56 & Supported \\
\hline
\end{tabular}

Note: $* * * \mathrm{p}<0.001$ 


\subsection{The Moderating Effect of Celebrity-Brand Congruence}

In Hypothesis 2, anticipation was that celebrity-brand congruence would moderate the link between CEC and brand relationship quality. To test the second hypothesis, the multiple group analysis through AMOS was employed. "Multiple group analysis is a method to test the difference of path coefficients between two groups" (Bae, 2011, p. 467). Using a median split technique, the study sample was divided into two subgroups, high $(\mathrm{n}=$ 179) and low $(n=118)$ level of celebrity-brand congruence. To check the overall moderating effect of celebrity-brand congruence, the difference in chi square between constrained and unconstrained models was compared. The findings indicated that two models differed significantly $\left(\Delta \chi^{2}(9)=25.35, p<0.01\right)$. Accordingly, further examination of moderating impact on each path was possible. As indicated in Table 4, celebrity-brand congruence significantly moderated the relationship between CEC and brand loyalty $\left(\Delta \chi^{2}(1)=4.28, \mathrm{p}<0.05\right)$, and this relationship revealed to be slightly stronger for the high level of celebrity-brand congruence group $(\beta=$ $0.47, \mathrm{p}<0.001)$ than for the group of low level $(\beta=0.65, \mathrm{p}<0.001)$, providing support for Hypothesis 2 .

Table 4. Results of moderation analysis

\begin{tabular}{|c|c|c|c|c|}
\hline \multirow[t]{2}{*}{ Hypothesis } & \multicolumn{2}{|c|}{$\begin{array}{l}\text { Celebrity-brand } \\
\text { congruence }\end{array}$} & \multirow[t]{2}{*}{$\Delta \chi^{2}(\mathrm{df}=1)$} & \multirow[t]{2}{*}{ Test results } \\
\hline & Low & High & & \\
\hline $\mathrm{H} 2: \mathrm{CEC} \rightarrow$ & $0.47 * * *$ & $0.65 * * *$ & $4.28 * *$ & Supported \\
\hline
\end{tabular}

Note: $* \mathrm{p}<0.05 ; * * \mathrm{p}<0.01 ; * * * \mathrm{p}<0.001$

\section{Discussion and Implications}

A number of previous research have investigated the direct relationship between CEC and consumer brand-related outcomes (Dwivedi et al., 2015; Spry et al., 2011; Dwivedi et al., 2014; Stafford et al., 2002; Wang et al., 2017). However, little is still known about underlying mechanisms in this relationship. In light of this, the present study aimed to address this gap through analyzing whether the link between CEC and brand loyalty was mediated of brand relationship quality using the meaning transfer theory. Furthermore, this study also intended to explore whether this link was moderated of celebrity-brand congruence. The results revealed that brand relationship quality had a partial mediating effect on CEC and brand loyalty. Moreover, it confirmed the moderating effect of celebrity-brand congruence on the relationship of CEC with brand relationships.

\subsection{Theoretical Implications}

The article contributes to the existing branding literature in two aspects. First, this study extends earlier theoretical findings by adding brand relationship quality as potential mediator of the association between CEC and brand loyalty. This finding aligns with existing studies indicating the influence of CEC on brand relationship quality (Dwivedi et al., 2016) and the bearing of brand relationship quality on brand commitment and brand loyalty (Albert and Merunka, 2013; Veloutsou, 2015; Valta, 2013).

Besides, it is important to note that brand relationship quality serve as a partial mediator in the relationship between CEC and brand loyalty. It means that CEC produces positive impacts on brand loyalty not only directly but also indirectly through brand relationships.

Second, this study is the first in the fashion luxury sector to explore the moderating role of celebrity-brand congruence in the relation between CEC and brand relationship quality. To be specific, CEC was more strongly related to brand relationship quality for high celebrity-brand congruence than for low one. High celebrity brand congruence may have a positive influence in advertised brand (Kamins, 1990), thus contributing towards building strong brand relationships.

\subsection{Managerial Implications}

The research also provides several suggestions for luxury marketers and advertisers alike. First, this research highlighted the mediating role of brand relationship quality between the influence of CEC on brand loyalty. This mediation mechanism provides luxury marketers a new insight into the process of achieving a demonstrable return on investments in celebrity endorsements. More specifically, luxury marketers should make investments 
on credible celebrity endorsers to establish deep and close brand connections with consumers that can lead to loyalty.

Another meaningful suggestion of this research refers to the moderating role of celebrity-brand congruence on the path between CEC and brand relationship quality. It is clearly evident that higher celebrity-brand congruence leads to higher brand relationships. Thus, in order to enhance interactions between the brand and consumer, luxury managers should carefully select a celebrity by taking into account not only credibility, but also suitability of the celebrity endorsement. For instance, luxury marketers should manage and lead ad hoc research in order to assess the levels of congruence (Fleck et al., 2012).

\section{Limitations and Future Research Direction}

Despite these meaningful implications, this research has a number of shortcomings. First, the sample for this research was focused on Korean consumers, thereby restricting generalizability of the results. Future studies may extend research by collecting broader sample in other countries.

Second, the current study identifies brand relationship quality as partial mediating construct linking CEC to brand loyalty. To deepen the understanding of this link, future studies may consider other possible mediating constructs such as brand knowledge, brand reputation, etc. Also, it may be interesting to research the potential moderating impact of the other constructs such as relationship length and the level of involvement.

\section{References}

Aaker, D. A. (1996). Building strong brands. New York: The Free Press.

Albert, N., \& Merunka, D. (2013). The role of brand love in consumer-brand relationships. Journal of Consumer Marketing, 30(3), 258-266. https://doi.org/10.1108/07363761311328928

Albert, N., Ambroise, L., \& Valette-Florence, P. (2017). Consumer, brand, celebrity: Which congruency produces effective celebrity endorsements? Journal of Business Research, 81, 96-106. https://doi.org/10.1016/j.jbusres.2017.08.002

Bae, B. (2011). Structural equation modelling with AMOS 19: Principles and practice. Seoul, Korea: Cheongram Book.

Caroll, B., \& Ahuvia, A. (2006). Some antecedents and outcomes of brand love. Marketing Letter, 17(2), 79-89. https://doi.org/10.1007/s11002-006-4219-2

Chaudhuri, A., \& Holbrook, M. B. (2001). The chain of effects from brand trust and brand affect to brand performance: The role of brand loyalty. Journal of Marketing, 65(2), 81-93. https://doi.org/10.1509/jmkg.65.2.81.18255

Crosby, L. A., Evans, K. R., \& Cowles, D. (1990). Relationship quality in services selling: An interpersonal influence perspective. Journal of Marketing, 54(3), 68-81. https://doi.org/10.2307/1251817

Doney, P. M., \& Cannon, J. P. (1997). An examination of the nature of trust in buyer-seller relationships. Journal of Marketing, 61(2), 35-52. https://doi.org/10.2307/1251829

Dwivedi, A., \& Johnson, L. W. (2013). Trust-commitment as a mediator of the celebrity endorser-brand equity relationship in a service context. Australasian Marketing Journal, 21(1), 36-42. https://doi.org/10.1016/j.ausmj.2012.10.001

Dwivedi, A., McDonald, R. E., \& Johnson, L. W. (2014). The impact of a celebrity endorser's credibility on consumer self-brand connection and brand evaluation. Journal of Brand Management, 21(7/8), 559-578. https://doi.org/10.1057/bm.2014.37

Dwivedi, A., Johnson, L. W., \& McDonald, R. E. (2015). Celebrity endorsement, self-brand connection and consumer-based brand equity. Journal of Product \& Brand Management, 24(5), 449-461. https://doi.org/10.1108/JPBM-10-2014-0722

Dwivedi, A., Johnson, L. W., \& McDonald, R. (2016). Celebrity endorsements, self-brand connection and relationship quality. International Journal of Advertising, 35(3), 486-503. https://doi.org/10.1080/02650487.2015.1041632

Escalas, J. E. (2004). Narrative processing: Building consumer connections to brands. Journal of Consumer Psychology, 14(1/2), 168-180. https://doi.org/10.1207/s15327663jcp1401\&2_19

Esch, F. R., Langner, T., Schmitt, B., \& Geus, P. (2006). Are brands forever? How knowledge and relationships affect current and future purchases. Journal of Product and Brand Management, 15(2), 98-105. 
https://doi.org/10.1108/10610420610658938

Fleck, N., Korchia, M., \& Roy, I. (2012). Celebrities in advertising: Looking for congruence or likability? Psychology \& Marketing, 29(9), 651-662. https://doi.org/10.1002/mar.20551

Fornell, C., \& Larcker, D. F. (1981). Evaluating structural equation models with unobservable variables and measurement error. Journal of Marketing Research, 18(1), 39-50. https://doi.org/10.2307/3151312

Fournier, S. (1994). A consumer-brand relationship framework for strategic brand management (PhD thesis). University of Florida.

Fournier, S. (1998). Consumers and their brands: Developing relationship theory in consumer research. Journal of Consumer Research, 24(4), 343-373. https://doi.org/10.1086/209515

Francisco-Maffezzoli, E. C., Semprebon, E., \& Prado, P. H. (2014). Construing loyalty through brand experience: The mediating role of brand relationship quality. Journal of Brand Management, 21(5), 446-458. https://doi.org/10.1057/bm.2014.16

Giovanis, A., \& Athanasopoulou, P. (2017). Consumer-brand relationships and brand loyalty in technology-mediated services. Journal of Retailing and Consumer Services, 40, 287-294. https://doi.org/10.1016/j.jretconser.2017.03.003

Gong, W., \& Li, X. (2017). Engaging fans on microblog: the synthetic influence of parasocial interaction and source characteristics on celebrity endorsement. Psychology \& Marketing, 34(7), 720-732. https://doi.org/10.1002/mar.21018

Hair, J. F., Sarstedt, M., Ringle, C. M., \& Mena, J. A. (2012). An assessment of the use of partial least squares structural equation modeling in marketing research. Journal of the Academy of Marketing Science, 40(3), 414-433. https://doi.org/10.1007/s11747-011-0261-6

Hess, J., \& Story, J. (2005). Trust-based commitment: multidimensional consumer-brand relationships. Journal of Consumer Marketing, 22(6), 313-322. https://doi.org/10.1108/07363760510623902

Hunt, S. D., Arnett, D. B., \& Madhavaram, S. (2006). The explanatory foundations of relationship marketing theory. Journal of Business \& Industrial Marketing, 21(2), 72-87. https://doi.org/10.1108/10610420610651296

Kamins, M. A. (1990). An investigation into the "match-up" hypothesis in celebrity advertising: When beauty may be only skin deep. Journal of Advertising, 19(1), 4-13. https://doi.org/10.1080/00913367.1990.10673175

McAlexander, J. H., Schouten, J. W., \& Koenig, H. F. (2002). Building brand community. Journal of Marketing, 66(1), 38-54. https://doi.org/10.1509/jmkg.66.1.38.18451

McCracken, G. (1989). Who is the celebrity endorser? Cultural foundations of the endorsement process. Journal of Consumer Research, 16(3), 310-321. https://doi.org/10.1086/209217

Min, J. H., Chang, H. J., Jai, T. M., \& Ziegler, M. (2019). The effects of celebrity-brand congruence and publicity on consumer attitudes and buying behavior. Fashion and Textiles, 6(10), 1-19. https://doi.org/10.1186/s40691-018-0159-8

Misra, S., \& Beatty, S.E. (1990). Celebrity spokesperson and brand congruence: An assessment of recall and affect. Journal of Business Research, 21(2), 159-173. https://doi.org/10.1016/0148-2963(90)90050-N

Nunnaly, J. C. (1978). Psychometric theory. New York: McGraw-Hill.

Ohanian, R. (1990). Construction and validation of a scale to measure celebrity endorsers' perceived expertise, trustworthiness, and attractiveness. Journal of Advertising, 19(3), 39-52.

https://doi.org/10.1080/00913367.1990.10673191

Oliver, R. L. (1999). Whence consumer loyalty? Journal of Marketing, 63, 33-44. https://doi.org/10.2307/1252099

Park, C. W., MacInnis, D. J., Priester, J., Eisingerich, A. B., \& Lacobucci, D. (2010). Brand attachment and brand attitude strength: conceptual and empirical differentiation of two critical brand equity drivers. Journal of Marketing, 74(6), 1-17. https://doi.org/10.1509/jmkg.74.6.1

Preacher, K. J., Rucker, D. D., \& Hayes, A. F. (2007). Addressing moderated mediation hypotheses: Theory, methods, and prescriptions. Multivariate Behavioral Research, 42(1), 185-227. https://doi.org/10.1080/00273170701341316 
Preacher, K. J., \& Hayes, A. F. (2008). Asymptotic and resampling strategies for assessing and comparing indirect effects in multiple mediator models. Behavior Research Methods, 40, 879-891. https://doi.org/10.3758/BRM.40.3.879

Ramaseshan, B., \& Stein, A. (2014). Connecting the dots between brand experience and brand loyalty: the mediating role of brand personality and brand relationships. Journal of Brand Management, 21(7/8), 664-683. https://doi.org/10.1057/bm.2014.23

Roberts, K., Varki, S., \& Brodie, R. (2013). Measuring the quality of relationships in consumer services: An empirical study. European Journal of Marketing, 37(1/2), 169-196. https://doi.org/10.1108/03090560310454037

Spry, A., Pappu, R., \& Cornwell, T. B. (2011). Celebrity endorsement, brand credibility and brand equity. European Journal of Marketing, 45(6), 882-909. https://doi.org/10.1108/03090561111119958

Stafford, M. R., Stafford, T. F., \& Day, E. (2002). A contingency approach: The effects of spokesperson type and service type on service advertising perceptions. Journal of Advertising, 31(2), 17-35. https://doi.org/10.108/00913367.2002.10673664

Till, B. D., \& Busler, M. (2000). The match-up hypothesis: Physical attractiveness, expertise, and the role of fit on brand attitude, purchase intent and brand beliefs. Journal of Advertising, 29(3), 1-13. https://doi.org/10.1080/00913367.2000.10673613

Tsiros, M., \& Mittal, V. (2000). Regret: A model of its antecedents and consequences in consumer decision making. Journal of Consumer Research, 26(4), 401-417. https://doi.org/10.1086/209571

Valta, K. S. (2013). Do relational norms matter in consumer-brand relationships? Journal of Business Research, 66(1), 98-104. https://doi.org/10.1016/j.jbusres.2011.07.028

Veloutsou, C. (2007). Identifying the dimensions of the product-brand and consumer relationship. Journal of Marketing Management, 23(1/2), 7-26. https://doi.org/10.1362/026725707X177892

Veloutsou, C. (2015). Brand evaluation, satisfaction and trust as predictors of brand loyalty: the mediator-moderator effect of brand relationships. Journal of Consumer Marketing, 32(6), 405-421. https://doi.org/10.1108/JCM-02-2014-0878

Wang, S. W., Kao, G. H. Y., \& Ngamsiriudom, W. (2017). Consumers' attitude of endorser credibility, brand and intention with respect to celebrity endorsement of the airline sector. Journal of Air Transport Management, 60, 10-17. https://doi.org/1016/j.jairtman.2016.12.007

\section{Copyrights}

Copyright for this article is retained by the author(s), with first publication rights granted to the journal.

This is an open-access article distributed under the terms and conditions of the Creative Commons Attribution license (http://creativecommons.org/licenses/by/4.0/). 